\title{
Knowledge, attitudes and practices related to cervical cancer screening in adult women: a hospital based cross-sectional study
}

\author{
Neeti Nisha S. Jha, Neha Choudhary*, Sunita Maheshwari
}

Department of Obstetrics and Gynaecology, Ravindra Nath Tagore Medical College, Udaipur, Rajasthan, India

Received: 13 September 2020

Accepted: 28 October 2020

\section{*Correspondence:}

Dr. Neha Choudhary,

E-mail: nehachoudhary1710@gmail.com

Copyright: (C) the author(s), publisher and licensee Medip Academy. This is an open-access article distributed under the terms of the Creative Commons Attribution Non-Commercial License, which permits unrestricted non-commercial use, distribution, and reproduction in any medium, provided the original work is properly cited.

\begin{abstract}
Background: The Pap smear is a reliable, inexpensive and effective screening test for cervical cancer; the second most common cancer among women worldwide. We aimed to determine women's knowledge, attitudes and practice towards Pap smear and barriers for the screening in a public hospital.

Methods: It was a hospital based cross sectional study on 300 women who were interviewed face-to-face with a structured questionnaire regarding their socio demographic features (8 questions), knowledge (20 questions), attitudes (7 statements) and practice (undertook test or not) towards Pap smear.

Results: A total of 320 women were approached for interview of which 300 responded of which $33.33 \%$ had heard of cervical cancer. At least one symptom and one risk factor were known to $13.33 \%$ and 20\% participants. Only $31.33 \%$ participants had heard, and $6.67 \%$ actually underwent screening test, however, $76.25 \%$ of the participants expressed a favourable attitude for screening.

Conclusions: Education level influences attitude towards screening and actual practice depends on age, income, and marital status. This study shows that despite the fact that women had suboptimal level of knowledge regarding cervical cancer, their attitude is favourable for screening. The knowledge and practice of women was inadequate and needs to be promoted.
\end{abstract}

Keywords: Cervical cancer, Knowledge, Attitude, Practice, PAP smear

\section{INTRODUCTION}

Cervical cancer is the second most common cancer in India in women accounting for $22.86 \%$ of all cancer cases in women and $12 \%$ of all cancer cases in both men and women. ${ }^{1}$ In India, one woman dies of cervical cancer every 8 minutes. $^{2}$ Every year, 122,844 women in India are diagnosed with cervical cancer and 67,477 die from the disease. $^{3}$

Cervical cancer is a malignant neoplasm arising from cells originating in cervix uteri. It is usually asymptomatic initially due to a long preinvasive state and has a bimodal peak: 35-39 years, 60-65 years. The main causative agent for cervical cancer is Human papilloma virus (HPV) infection, with type 16, 18 carrying high risk, and type 6, 11 , low risk. Infection with HPV type 16 and 18 causes $75 \%$ of cervical cancer globally. ${ }^{4}$ Other causes are factors increasing the risk of sexually transmitted diseases (STDs) i.e. multiparity, multiple sex partners, coitus before the age of 18 , poor personal hygiene, poor socio-economic status, smoking, long term oral contraceptive pills (OCP) usage, immunosuppressed individuals ${ }^{5}$

The most common symptoms of cervical cancer are bleeding per vaginum- intermenstrual bleeding, post coital bleeding, or discharge- creamy, dirty brown, offensive in early stages and deep pelvic pain, urinary incontinence, dysuria, frequency, rectal pain, low backache/flank pain 
(hydronephrosis), weight loss, anorexia, malaise in advanced stage.

However, the silver lining in this grim scenario is that cervical cancer is preventable: primary preventionvaccination against HPV, secondary prevention- screening (Pap smear).

Vaccines against cervical cancer are available in Indian markets, but the main limiting factor for its prevalent usage is its cost, especially in a developing country like India. Therefore, we need to put more of our efforts and resources towards secondary prevention. Experience from developed countries have also shown that well planned, organized cervical cancer screening programs and augmentation of the health care services to treat the disease at pre-cancer stage can significantly reduce the burden of cervical cancer.

Detection and treatment of cervical pre-cancer is much less expensive than treatment of invasive cancer and cervical cancer screening is one of the most cost-effective public health interventions if organized properly. However, the success and benefits of screening at a national level as a public health program to control and prevent cervical cancer depend to a great extent on the level of awareness of the potential beneficiaries.

\section{Pap smear}

It is an effective and easy way of screening for cervical cancer. The advised time for initiation is at 21 years of age (regardless of age of first intercourse). Ayre's spatula and endocervical brush is the instrument used for taking the sample and 95\% ethyl alcohol and ether are used as fixatives. First slide prepared by ayre's spatula over the portio vaginalis of cervix and the second slide prepared from the endocervix using the endocervical brush. Control slides prepared from posterior fornix of vagina.

Pap smear test has been credited with dramatically reducing the number of cases of cervical cancer in developed countries. ${ }^{6}$ It has been found that in many developed countries the annual incidence and prevalence of cervical cancer has decreased by $50-70 \%$ after introduction of population-based screening. ${ }^{7}$

In India, however, there are still several barriers to cervical cancer screening uptake by women and $>95 \%$ women in India have never been screened for cervical cancer. ${ }^{8}$

The present study aims to provide inputs toward designing suitable information, education, and communication strategies to address various issues standing in our way to fight cervical cancer. The objectives of the study are to determine women's knowledge, attitudes and practice towards Pap smear and to determine barriers for the cervical cancer screening in a public hospital.

\section{METHODS}

It was a questionnaire based cross-sectional hospital study carried out on 300 women visiting the outpatient department in Pannadhaya Zanana Hospital, associated with R.N.T. Medical College, Udaipur. The period of study was August and September 2017 with non-random sampling i.e. sequential inclusion of women who met the study criteria. Data were collected via face-to-face interviews by one trained interviewer using a structured questionnaire. The questionnaire included demographic characteristics (8 questions), knowledge (20 questions), attitudes (7 statements) and practice 9 undertook test or not towards Pap smear.

The sociodemographic characteristics included age, educational status, occupation, marital status, age of marriage, number of children borne, preferred mode of contraception and per capita family income. The knowledge was assessed using a 20 points scale which had dichotomous response, that is, correct and incorrect. Each correct response was scored as 1 and incorrect as 0 . A score $50 \%$ ( $\geq 10$ correct responses) was considered as optimal.

Attitude was assessed by 7 statements regarding cervical cancer screening and risk factors responses to which were categorized as 3-point scale disagree, neutral, and agree. Attitude was considered as favorable for screening if four or more "agree" responses were obtained. Those who had been screened for cervical cancer through pap-smear were regarded as having good practice.

\section{Inclusion criteria}

The inclusion criteria for the study were as follows: women $>15$ years of age and women giving consent for participation in the study.

\section{Exclusion criteria}

The exclusion criteria for the study were as follows: women not giving consent for participation in the study and a verbal consent was taken from all women before starting the questionnaire.

\section{RESULTS}

Of the 320 patients approached for the study, 300 responded in favor of participating, making the response rate $93.75 \%$. The sociodemographic profile of study subjects is mentioned in (Table 1,2).

Majority of women i.e. (41\%) belonged to 26-35 years of age, followed by $21.5 \%$ in $36-45$ years of age. Most women were married $(93 \%)$, had primary level of education $(41 \%)$, and the most common parity was 2 (47\%). The preferred mode of contraception for most women in our study was female sterilization (34\%). Most 
study subjects were married before 21 years of age $(51.7 \%)$.

Table 1: Socio-demographic profile of study subjects.

\begin{tabular}{|ll|}
\hline Characteristic & Number (\%) \\
\hline Age in years & \\
\hline $15-25$ & $21(7)$ \\
\hline $26-35$ & $123(41)$ \\
\hline $36-45$ & $62(21.5)$ \\
\hline $46-55$ & $54(18)$ \\
\hline$>55$ & $37(12.5)$ \\
\hline Educational Status & \\
\hline No formal education & $51(17)$ \\
\hline Primary education & $123(41)$ \\
\hline Secondary education & $69(23)$ \\
\hline Graduate & $33(11)$ \\
\hline Marital status & \\
\hline Married & $279(93)$ \\
\hline Unmarried & $21(7)$ \\
\hline
\end{tabular}

Table 2: Socio-demographic profile of study subjects.

\begin{tabular}{|ll|}
\hline $\begin{array}{l}\text { Characteristic } \\
\text { Age at marriage }\end{array}$ & \multicolumn{1}{l|}{ Number $(\%)$} \\
\hline$<21$ years & $161(51.7)$ \\
\hline $21-26$ years & $83(27.8)$ \\
\hline$>27$ years & $63(21)$ \\
\hline Occupation & $204(68)$ \\
\hline Housewives & $21(7)$ \\
\hline Working & $75(25)$ \\
\hline Others & $79(26.5)$ \\
\hline Per capita family income \\
\hline$<1000$ & $44(14.5)$ \\
\hline $1001-5000$ & $36(12)$ \\
\hline $5001-10000$ & $72(24)$ \\
\hline $10001-15000$ & $139(44.6)$ \\
\hline$>15000$ & $112(34)$ \\
\hline Preferred mode of contraception \\
\hline Female sterilization & $3(1)$ \\
\hline Male sterilization & $30(10)$ \\
\hline OC Pills & $6(2)$ \\
\hline IUD & $36(12)$ \\
\hline Condoms & $142(28.5)$ \\
\hline Non user & $37(12.5)$ \\
\hline Menopausal & \\
\hline
\end{tabular}

In our study, only $33.33 \%$ women had heard of cervical cancer, $29.2 .5 \%$ of women knew about at least one symptom of the same, most common symptoms known was intermenstrual bleeding. Knowledge of risk factors was limited to $27.7 \%$ of women, with multiple sexual partners being the most common risk factor known to study participants. $27.7 \%$ of women had heard about screening for cervical cancer i.e. Pap smear. Coming to knowledge regarding pap smear, $15 \%$ of women knew when they should get screening done and the same percentage knew where they could get it done. A mere $1 \%$ was aware of a vaccine for prevention of cervical cancer.

Table 3: Details of responses of knowledge of study participants.

\begin{tabular}{|ll|}
\hline Variable & $\mathbf{n = 3 0 0}(\boldsymbol{\%})$ \\
\hline Heard of cervical cancer? & $100(33.33)$ \\
\hline Knowledge of symptoms & \\
\hline Bleeding between periods & $87(29.2)$ \\
\hline foul smelling vaginal discharge & $69(23)$ \\
\hline Postmenopausal bleeding & $14(4.7)$ \\
\hline Periods heavier or longer than usual & $13(4.2)$ \\
\hline $\begin{array}{l}\text { Knowledge of cervical cancer } \\
\text { screening }\end{array}$ \\
\hline Utility of screening & $31(10.2)$ \\
\hline Age of screening & $45(15)$ \\
\hline Screening frequency & $23(7.5)$ \\
\hline Vaccine availability & $14(4.7)$ \\
\hline Age for HPV vaccine & $3(10)$ \\
\hline Place where screening can be done & $45(15)$ \\
\hline Knowledge of risk factors & \\
\hline Viral (HPV) infection & $3(1)$ \\
\hline Multiple sexual partners & $83(27.7)$ \\
\hline Early age of coitus & $49(15.5)$ \\
\hline Multiple pregnancies (>5) & $29(9.5)$ \\
\hline Tobacco/smoking & $35(11.70$ \\
\hline History of STDs & $21(7)$ \\
\hline Poor menstrual hygiene & $51(17)$ \\
\hline Prolonged use of birth control pills & $67(22.50$ \\
\hline $\begin{array}{l}\text { Heard of cervical cancer screening i.e } \\
\text { ap smear? }\end{array}$ & $83(27.7)$ \\
\hline
\end{tabular}

Taking into account the above, the knowledge of study participants regarding cervical cancer and cervical cancer screening i.e. Pap smear was poor in $82 \%$ and $87 \%$ respectively. The same is shown in table 4.

When the demographic data is taken into account, education seems to play a role in the level of knowledge. Among women who have had college education, $14.5 \%$ women had satisfactory knowledge as opposed to none among the women with only primary or no education $(p<0.05)$. Similarly, $13.3 \%$ of employed women had adequate knowledge as opposed to $4.67 \%$ of women who were not working $(\mathrm{p}<0.05)$. Women who got married after 21 years of age had adequate knowledge (9.6\%) more commonly than women who got married before attaining 21 years of age; however, this finding was not statistically significant.

As far as attitude of the participants is concerned, $47.7 \%$, $41 \%$ and $41 \%$ women respectively thought that going for Pap smear might be embarrassing/unpleasant and that it needs not to be done if one does not have any symptoms, or the doctor didn't prescribe it. Details of responses regarding Attitude of study subjects is given in table 6 . 
Table 4: Details of knowledge of study participants.

\begin{tabular}{|ll|}
\hline Cervical cancer & n (\%) \\
\hline Poor knowledge $(<\mathbf{1 0}$ correct answers) & $245(82)$ \\
\hline $\begin{array}{l}\text { Satisfactory knowledge }(>\mathbf{1 0} \text { correct } \\
\text { answers) }\end{array}$ & $54(18)$ \\
\hline Cervical cancer screening & $261(87)$ \\
\hline Poor knowledge $(<10$ correct answers) & $39(13)$ \\
\hline $\begin{array}{l}\text { Satisfactory knowledge }(>10 \text { correct } \\
\text { answers) }\end{array}$ & \\
\hline
\end{tabular}

Table 5: Comparison between level of knowledge of cervical cancer screening and socio demographic features of study participants.

\begin{tabular}{|lll|}
\hline $\begin{array}{l}\text { Demographic } \\
\text { feature }\end{array}$ & $\begin{array}{l}\text { Poor } \\
\text { knowledge }\end{array}$ & $\begin{array}{l}\text { Satisfactory } \\
\text { knowledge }\end{array}$ \\
\hline Occupation & $90(33.7)$ & $40(13.3)$ \\
\hline Employed & $155(51.8)$ & $14(6.67)$ \\
\hline Housewives & \\
\hline Education & $177(59)$ & 0 \\
\hline Some schooling & $68(22.67)$ & $43(14.5)$ \\
\hline Graduate & & $15(4.8)$ \\
\hline Age at marriage & $141(47)$ & $29(9.6)$ \\
\hline$<21$ years & $104(38.6)$ & \\
\hline$>21$ years & & \\
\hline
\end{tabular}

Table 6: Details of response of attitude of study participants.

\begin{tabular}{|l|l|}
\hline Variables & $\mathbf{n = 3 0 0 ( \% )}$ \\
\hline $\begin{array}{l}\text { It would be painful to have Pap } \\
\text { smear }\end{array}$ & $33(10.9)$ \\
\hline $\begin{array}{l}\text { Having Pap smear is } \\
\text { embarrassing/unpleasant }\end{array}$ & $143(47.7)$ \\
\hline $\begin{array}{l}\text { Pap smear is not necessary without } \\
\text { any signs and symptoms }\end{array}$ & $123(41)$ \\
\hline $\begin{array}{l}\text { It is difficult to get to a Pap smear } \\
\text { clinic }\end{array}$ & $34(11.4)$ \\
\hline $\begin{array}{l}\text { I won't have cervical cancer as I } \\
\text { don't have the risk factors }\end{array}$ & $32(10.2)$ \\
\hline $\begin{array}{l}\text { I'm afraid something wrong will get } \\
\text { detected if I go for a Pap smear }\end{array}$ & $25(8.3)$ \\
\hline $\begin{array}{l}\text { I don't need pap smear as my doctor } \\
\text { didn't advice it }\end{array}$ & $123(41)$ \\
\hline
\end{tabular}

However, after explaining about the pathogenesis of cervical cancer and possible benefits of its screening, another question was asked: would you wish to be screened for cervical cancer if a free screening was offered? $76.25 \%$ of women agreed to it, showing the attitude to be favorable.

Nevertheless, the practice of Pap smear was still poor, only $6.67 \%$ of the study participants had ever been screened for cervical cancer.

\section{DISCUSSION}

Overall, the knowledge of study participants was inadequate, practice poor but the attitude was optimistic. Only $13 \%$ women had adequate knowledge regarding Pap smear screening, and only $6.67 \%$ had actually practiced it.

In a study on Vietnamese women born in Australia, 87\% of the women heard about Pap smear and $75 \%$ had a Pap smear. ${ }^{9}$ This percentages in a study on the American women-Vietnamese in California were reported $74 \%$ and $76 \%$, respectively. ${ }^{10}$ Idestrom and colleagues in Sweden reported that $95 \%$ of the subjects were aware of the Pap test for cervical cancer screening. ${ }^{11}$ These findings are in stark contrast of our study where only $27.7 \%$ of women had heard of pap smear, and $6.67 \%$ actually undergone it. However, the findings of adequate knowledge in $13 \%$ women found in our study is comparable to $11 \%$ found in a study in Bhopal by Bansal et al, in Cameroon by Tebeu et al and in Ethiopia by Yifru and Asheber. ${ }^{12-14}$ Similarly, in the study by Roy et al in Kolkata, poor knowledge (84\%) about cervical cancer and its screening has been reported from a study conducted on women who attended the hospitals. ${ }^{15}$ This might be attributed to lower socio demographic profile of the participants and lower level of awareness in developing country compared to developed ones.

However, good knowledge has been reported from three studies conducted on nurses. ${ }^{16-18}$ Obviously, nurses being health care providers would have better knowledge.

On the other hand similar to our study, community based studies have reported that 2-6.9\% of women ever got tested. ${ }^{8,19}$ Seow et al believe the means of increasing the acceptance of the Pap smear are culture-specific and must address the appropriate health beliefs and attitudes. Such efforts should include not only influencing awareness and perceptions through public education but also reducing barriers by creating an appropriate environment for the delivery of this important health service. ${ }^{20}$

Coughlin and colleagues reported that reasons for not receiving a Pap smear by women in U.S included lack of physician recommendation, haven't had any problems and too painful and unpleasant to be tested. ${ }^{21}$ This study documented that common reason for non-participation was no physicians' and other health providers' recommendation and lack of knowledge about Pap smear. These finding are almost consistent with results of the study in Kerman. ${ }^{22}$ Some studies have shown that physician recommendation to do a cancer screening test is one of the strongest independent predictors of a woman's decision to be screened. ${ }^{23}$ This is also consistent with our results.

Intermenstrual bleeding was the, most common mentioned symptom; this finding is similar to study done in Kerala8 and Ahmedabad. ${ }^{16}$ The most common risk factor mentioned was multiple sexual partners. John et al have 
reported similar findings in his dissertation submitted to the Muhimbili University of Health and Allied Sciences, Songea in 2011 and The University of Iowa in 2012, respectively. ${ }^{24,25}$

\section{CONCLUSION}

Our study shows a poor level of knowledge among the population, but a favorable attitude for screening. Only $33.3 \%$ women had heard of cervical cancer, but of the other women, once explained about the disease and its screening $76.25 \%$ were willing to get screened if offered free of cost. However, only $6.67 \%$ women had actually had a Pap smear till date. The main reasons for this lack in practice was lack of awareness about cervical cancer and its screening test and being symptomless. On comparing the demographic profile with level of knowledge, it can be concluded that education does have a positive effect on it. Employed women had higher education. Educated women had higher knowledge than housewives. Women with higher per capita family income had better attitude regarding cervical intermenstrual bleeding was the most common symptom known to women. Multiple sexual partners were the commonest risk factor known. To overcome this lack of knowledge, we need to have population-based screening programs, efficient mass media campaigns, and breaking cultural barriers wherein women in India do not feel shy to discuss the diseases affecting the sexual organs. Strategic communication targeting eligible women, universal availability of screening facilities in public health facilities may increase the uptake of screening.

Funding: No funding sources

Conflict of interest: None declared

Ethical approval: The study was approved by the Institutional Ethics Committee

\section{REFERENCES}

1. Guidelines for cervical cancer screening programme (2004-2005). World Health Organization. 2006. WHO_India_CCSP_guidelines_2005.pdf. Accessed on 13 August 2020.

2. WHO Summary report on HPV \& cervical cancer statistics in India. World Health Organization. 2008. Accessed on 13 August 2020.

3. ICO Information Centre on HPV and cancer (Summary Report 2014-08-22). Human Papilloma virus and Related Diseases in India. 2014. Accessed on 13 August 2020.

4. Walboomers JM, Jacobs MV, Manos MM, Bosch FX, Kummer JA, Shah KV, et al. Human Papilloma virus is a necessary cause of invasive cervical carcinoma worldwide. J Pathol. 1999;189:12-9.

5. Gadducci A, Barsotti C, Cosro S, Domenici L, Riccardo, Genazzani A. Smoking habit, immune suppression, oral contraceptive use and HRT use and cervical carcinogenesis: A review of the literature. Gynecol Endocrinol. 2011;27:597-604.
6. Canavan TP, Doshi NR. Cervical cancer: Am Fam Physician. 2000;61:1369-76.

7. Guidelines for cervical cancer screening. Government of India and WHO Collaborative Program. 2012. Accessed on 13 August 2020.

8. Aswathy S, Quereshi MA, Kurian B, Leelamoni K. Cervical carcinoma screening: Current knowledge and practice among women in a rural population of kerala, India. Indian J Med Res. 2012;136:205-10.

9. Cheek J, Fuller J, Gilchrist S, Maddock A, Ballantyne A. Vietnamese women and Pap smears: issues in promotion. Aust N Z J Public Health. 1999;23:72-6.

10. Nguyen TT, McPhee SJ, Nguyen T, Lam T, Mock J. Predictors of cervical Pap smear screening awareness, intention, and receipt among Vietnamese-American women. Am J Prev Med. 2002;23(3):207-14.

11. Idestrom M, Milsom I, Andersson-Ellstrom A. Knowledge and attitudes about the Pap-smear screening program: a population-based study of women aged 20-59 years. Acta Obstet Gynecol Scand. 2002;81:962-7.

12. Bansal AB, Pakhare AP, Kapoor N, Mehrotra R, Kokane AM. Knowledge, attitude and practices related to cervical cancer among adult women: A hospital-based cross-sectional study. J Nat Sc Biol Med. 2015:6:324-8.

13. Tebeu PM, Major AL, Rapiti E, Petignat $P$, Bouchardy C, Sando Z et al. The attitude and knowledge of cervical cancer by Cameroonian women; a clinical survey conducted in Maroua, the capital of Far North Province of Cameroon. Int. J Gynecol Cancer. 2008;18:761-5.

14. Yifru T, Asheber G. Knowledge, attitude and practices of screening for carcinoma of the cervix among reproductive health clients at three teaching hospitals, Addis Ababa, Ethiopia. Ethiop J Reprod Health. 2008;2.

15. Roy B, Tang TS. Cervical cancer screening in Kolkata, India: Beliefs and predictors of cervical cancer screening among women attending a women's health clinic in Kolkata, India. J Cancer Educ. 2008;23:253-9.

16. Goyal A, Gunvant V, Shrivastava A, Verina R, Modi A. Knowledge, attitude and practices about cervical cancer screening among nursing staff in a teaching hospital. Int J Med Sci Public Health. 2013;2:249-53.

17. Shekhar S, Sharma C, Thakur S, Raina N. Cervical cancer screening: Knowledge, attitude and practices among nursing staff in a tertiary level teaching institution of rural India. Asian Pac J Cancer Prev. 2013;14:3641-5.

18. Shah V, Vyas S, Singh A, Shrivastava M. Awareness and knowledge of cervical cancer and its prevention among the nursing staff of a tertiary health institute in Ahmedabad, Gujarat, India. ecancer. 2012;6:270.

19. Asthana S, Labani S. Factors Associated with Attitudes of Rural Women Toward Cervical Cancer Screening. Indian Journal of Community Medicine. 2013;38:246-8. 
20. Seow A, Wong ML, Smith WC, Lee HP. Beliefs and attitudes as determinants of cervical cancer screening: a community-based study in Singapore. Prev Med. 1995;24:134-41.

21. Coughlin S, Breslau E, Thompson T, Benard V. Physician recommendation for Papanicolaou testing among US women. Cancer Epidemiol Biomarkers Prev. 2005;14:1143-8.

22. Soltanahmadi Z, Abbaszadeh A, Tirgari B. A Survey on the rate and causes of women's participation or nonparticipation in breast and cervical cancers screening programs. The Iranian Journal of Obstetrics, Gynecology and Infertility. 2010;13:3746.

23. Karimi H, Sam S. Effect of breast self-examination (BSE) education on increasing women's knowledge and practice. J Babol Univ Med Sci. 2005;27:61-8.
24. John J. The knowledge, attitude and practice and perceived barrier towards screening for premalignant lesions among women aged 18 years and above in Songea Urban, Ruvana [dissertation], Muhimbil. Univ Health Allied Sci. 2011. Accessed on 13 August 2020.

25. Beining RM. Screening for cervical cancer; An exploratory study of urban women in Tamil Nadu, India [dissertation]. University of Lowa. 2012. Accessed on 13 August 2020.

Cite this article as: Jha NSS, Neha Choudhary N, Maheshwari S. Knowledge, attitudes and practices related to cervical cancer screening in adult women: a hospital based cross-sectional study. Int J Reprod Contracept Obstet Gynecol 2020;9:4974-9. 